\title{
BLOOD PRESSURE IN BLACKS AND WHITES AND ITS RELATIONSHIP TO DIETARY SODIUM AND POTASSIUM INTAKE
}

\author{
A. Roberto Frisancho, William R. Leonard and Laura A. Bollettino \\ Center for Human Growth and Development and Department of Anthropology, \\ University of Michigan, Ann Arbor, MI 48109, U.S.A.
}

(Received in revised form 30 January 1984)

\begin{abstract}
The 24-hour dietary intake and blood pressure of 1928 black and 9739 white adults derived from the data sets of the first US National Health and Nutrition Examination Survey (NHANES I) of 1971-1974 were analyzed. Contrary to expectation, the absolute and relative intakes of sodium and potassium in blacks were less than those of whites. However, because the difference in potassium was greater than the difference in sodium, blacks did have a significantly higher sodium/potassium ratio than whites. Blacks had significantly higher blood pressure than whites even when adjusted for differences in sodium/potassium ratio. It is concluded that the higher blood pressure and prevalence of hypertension in blacks does not appear to be a function of an absolutely greater dietary sodium intake, but related to a relatively low intake of potassium. It is possible that blacks have a greater sensitivity than whites to the hypertensinogenic effects of sodium which, coupled with the relatively low dietary intake of potassium, accounts for their increased blood pressure.
\end{abstract}

\section{INTRODUCTION}

THERE is a great deal of evidence indicating that blacks have higher blood pressure and a higher prevalence of hypertension than whites. At present the extent to which these differences are due to differences in genetic susceptibility or environmental factors such as differences in dietary intakes of sodium and potassium is not well defined. Some studies have shown that blacks either ingest diets containing greater amounts of sodium or excrete more sodium than whites [1-5], while others have not found differences in sodium intake [6-9]. Similarly, studies on plasma renin activity indicate that blacks ingest less dietary potassium than whitcs [6], but this finding has not yet been confirmed by other studies. In search of possible explanations for the greater prevalence of hypertension among blacks than whites, we have analyzed the 24-hr dietary intakes collected during the first National Health and Nutrition Examination Survey (NHANES 1) of 1971-1974 in the United States. Furthermore, we have evaluated the relationship of both dietary sodium and potassium to blood pressurc in both blacks and whites.

\section{MATERIALS AND METHODS}

\section{Sample and measurements}

This study is based on a cross-sectional samplc of whites and blacks derived from the data sets of the first National Health and Nutrition Examination Survey of 1971-1974. This survey was concluded by the National Center for Health Statistics according to a multistage, stratified probability sample which included the selection of 28,043 persons that 
represented the 194 million noninstitutionalized civilians, aged 1-74 yr, of the United States. Of the 28,043 individuals who comprised the sample population for NHANES I, $20,749(74 \%)$ were examined. At the time of the examination when anthropometric measurements were obtained, 16,459 individuals were aged 18-74 yr. From this sample we selected a total of 11,667 blacks and whites ranging in age from 20 to $74 \mathrm{yr}$, who were not on any special diet or medication for hypertension.

This study is based on measurements of height, weight, skinfold thickness [10], blood pressure [11], and 24-hr dietary intake (12). The general protocol for the data collection is given in these publications.

\section{Analyses}

The analytical procedure was as follows. First, base 10 logarithms were taken of all the independent variables so as to correct for non-normal distributions. Second, the sample was divided into age, race, and sex groups. The age groups were: $20-24,25-34,35-44$, 45-54, 55-64 and 65-74 years old. Age, sex, and race categorization was performed for each univariate model. The independent variables that were found to be significantly different among the blacks and whites were included as the covariate variables when comparing the blood pressures. All comparisons and evaluations of the significance of the difference in blood pressures between blacks and whites were based upon analyses of variance and covariance. The analyses of variance permitted the determination of variables that were significantly different between blacks and whites, while the analyses of covariance enabled comparisons of mean blood pressures of blacks and whites at an equal or adjusted value of the independent variable (such as calorie intake and body size). In this manner, the comparisons of mean blood pressures were corrected for the effects of the independent variables.

\section{RESULTS}

As shown in Table 1 in all age groups, except among the 25-34-yr-old males and the 20-24-yr-old females, the dietary intake of sodium and potassium is lower in blacks than in whites. These population differences remain even when the sodium and potassium intakes per 1000 calories are compared. On the other hand, the sodium/potassium ratios

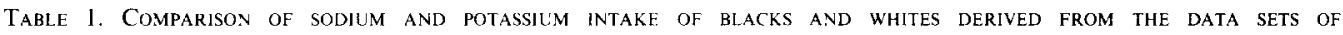
NIIANES I OF 1971 -1975

\begin{tabular}{|c|c|c|c|c|c|c|c|c|c|c|c|c|c|c|}
\hline \multirow{2}{*}{$\begin{array}{l}\text { Age } \\
(\mathrm{Yr})\end{array}$} & \multirow[b]{2}{*}{ Race } & \multirow[b]{2}{*}{$N$} & \multicolumn{2}{|c|}{$\log \mathrm{Na}$ intake } & \multicolumn{2}{|c|}{$\log \mathrm{K}$ intake } & \multicolumn{2}{|c|}{$\begin{array}{c}\log \text { calorie } \\
\text { intake }\end{array}$} & \multicolumn{2}{|c|}{$\log (\mathrm{Na} / \mathrm{K})$} & \multicolumn{2}{|c|}{$\frac{\log }{(\mathrm{Na} / 1000 \mathrm{cal})}$} & \multicolumn{2}{|c|}{$\begin{array}{c}\log \\
(\mathrm{K} / 1000 \mathrm{cal})\end{array}$} \\
\hline & & & Mean & $\mathrm{SD}$ & Mean & $\mathrm{SD}$ & Mean & $\mathrm{SD}$ & Mean & $\mathrm{SD}$ & Mean & $\mathrm{SD}$ & Mean & SD \\
\hline \multicolumn{15}{|c|}{ Males } \\
\hline \multirow[t]{2}{*}{$20-24$} & W & 421 & $3.44 * *$ & 0.26 & $3.46^{* *}$ & 0.23 & $3.44 * *$ & 0.18 & $-0.015^{*}$ & 0.25 & $3.00^{*}$ & 0.21 & $3.01^{* *}$ & 0.16 \\
\hline & $\mathrm{B}$ & 80 & 3.30 & 0.31 & 3.23 & 0.29 & 3.35 & 0.22 & 0.065 & 0.24 & 2.95 & .20 & 2.88 & 0.19 \\
\hline \multirow[t]{2}{*}{$25-34$} & W & 664 & 3.40 & 0.26 & $3.44^{* *}$ & 0.21 & 3.40 & 0.17 & $-0.036^{*}$ & 0.25 & 3.00 & 0.22 & $3.03^{* *}$ & 0.16 \\
\hline & B & 113 & 3.35 & 0.27 & 3.32 & 0.24 & 3.38 & 0.18 & 0.028 & 0.27 & 2.97 & 0.23 & 2.95 & 0.16 \\
\hline \multirow{2}{*}{$35-44$} & W & 554 & $3.41 * *$ & 0.25 & $3.43 * *$ & 0.20 & $3.38^{*}$ & 0.17 & -0.018 & 0.22 & 3.03 & 0.21 & $3.05^{* *}$ & 0.14 \\
\hline & B & 79 & 3.31 & 0.33 & 3.28 & 0.26 & 3.33 & 0.23 & 0.030 & 0.35 & 2.99 & 0.26 & 2.95 & 0.21 \\
\hline \multirow[t]{2}{*}{$45 \quad 54$} & $W$ & 636 & $3.36 * *$ & 0.25 & $3.39 * *$ & 0.19 & $3.34 * *$ & 0.17 & $-0.025^{* *}$ & 0.23 & 3.03 & 0.21 & $3.05 * *$ & 0.15 \\
\hline & B & 116 & 3.27 & 0.26 & 3.15 & 0.31 & 3.25 & 0.22 & 0.117 & 0.28 & 3.02 & 0.19 & 2.91 & 0.20 \\
\hline \multirow[t]{2}{*}{$55-64$} & W & 431 & $3.34 * *$ & 0.28 & $3.36^{* *}$ & 0.20 & $3.29 * *$ & 0.18 & -0.025 & 0.26 & $3.05^{*}$ & 0.21 & $3.07 * *$ & 0.15 \\
\hline & $B$ & 69 & 3.20 & 0.25 & 3.20 & 0.30 & 3.22 & 0.20 & 0.002 & 0.26 & 2.98 & 0.20 & 2.98 & 0.22 \\
\hline \multirow[t]{2}{*}{6574} & W & 1098 & $3.29^{* *}$ & 0.24 & $3.32^{* *}$ & 0.20 & $3.23^{* *}$ & 0.17 & $-0.023^{*}$ & 0.23 & $3.06^{* *}$ & 0.19 & $3.09^{* * *}$ & 0.15 \\
\hline & B & 221 & 3.14 & 0.32 & 3.11 & 0.30 & 3.15 & 0.19 & 0.028 & 0.27 & 2.99 & 0.25 & 2.96 & 0.23 \\
\hline \multicolumn{15}{|c|}{ Females } \\
\hline \multirow[t]{2}{*}{$20-24$} & w & 950 & 3.21 & 0.29 & 3.23 & 0.25 & 3.18 & 0.19 & $-0.020^{* *}$ & 0. & 3.0 & 0.22 & $3.04^{* *}$ & 0.18 \\
\hline & $\mathrm{B}$ & 255 & 3.17 & 0.33 & 3.13 & 0.27 & 3.19 & 0.19 & 0.040 & 0.31 & 2.99 & 0.26 & 2.95 & 0.21 \\
\hline \multirow[t]{2}{*}{$25-34$} & W & 1522 & $3.20^{* *}$ & 0.29 & $3.25^{*}$ & 0.24 & $3.17^{*}$ & 0.20 & $-0.050^{* *}$ & 0.26 & $3.03^{* *}$ & 0.21 & $3.07^{* *}$ & 0.17 \\
\hline & B & & 3.1 & 0.34 & 3.0 & 0.34 & & & 0.009 & 0. & 2.95 & 0.25 & 2.94 & 0.26 \\
\hline \multirow[t]{2}{*}{$35-44$} & W & 1240 & $3.20^{* * *}$ & 0.26 & $3.25^{* *}$ & 0.21 & $3.17^{* * *}$ & 0.18 & $-0.057^{* *}$ & 0.24 & $3.03^{* *}$ & 0.20 & $3.09^{* *}$ & 0.17 \\
\hline & B & 283 & 3.07 & 0.30 & 3.07 & 0.26 & 3.10 & 0.20 & -0.003 & 0.30 & 2.97 & 0.23 & 2.97 & 0.21 \\
\hline \multirow[t]{2}{*}{$45-54$} & $w$ & 742 & $3.18^{* * *}$ & 0.27 & $3.25^{* *}$ & 0.21 & 3.1 & 0.19 & -0.067 & 0.26 & $3.04^{* *}$ & 0.21 & $3.10^{* *}$ & 0.16 \\
\hline & B & & & 0.34 & 3.0 & 0.27 & 3.0 & & -0 & & 2.95 & 0.27 & 2. & 0.21 \\
\hline \multirow[t]{2}{*}{$55-64$} & W & 439 & $3.15^{* *}$ & 0.28 & $3.24^{* *}$ & 0.20 & & 0.16 & -0.098 & 0.27 & $3.03^{*}$ & 0.22 & & 0.16 \\
\hline & B & 74 & 3.03 & 0.24 & 3.10 & 0.26 & 3.05 & 0.20 & -0.074 & 0.26 & 2.97 & 0.22 & 3.05 & 0.18 \\
\hline \multirow[t]{2}{*}{$65-74$} & W & 1039 & $3.13^{* *}$ & 0.25 & $3.22^{* *}$ & 0.20 & $3.09 * *$ & 0.17 & -0.092 & 0.25 & $3.04^{* *}$ & 0.20 & $3.13^{* *}$ & 0.16 \\
\hline & B & 193 & 3.01 & 0.36 & 3.07 & 0.28 & 3.02 & 0.21 & -0.057 & 0.34 & 2.99 & 0.30 & 3.05 & 0.20 \\
\hline
\end{tabular}

${ }^{*} p<0.05,{ }^{* *} p<0.005$. 
TABLE 2. COMPARISON OF ANTHROPOMETRIC CHARACTERISTICS AND BLOOD PRESSURE OF BLACKS AND WHITES DERIVED FROM THE DATA SETS OF NHANES I OF 1971-1974

\begin{tabular}{|c|c|c|c|c|c|c|c|c|c|c|c|c|c|c|}
\hline \multirow{2}{*}{$\begin{array}{l}\text { Age } \\
\text { (yr) }\end{array}$} & \multirow[b]{2}{*}{ Race } & \multirow[b]{2}{*}{$N$} & \multicolumn{2}{|c|}{ Height $(\mathrm{cm})$} & \multicolumn{2}{|c|}{ Weight (kg) } & \multicolumn{2}{|c|}{$\begin{array}{c}\log (\text { body } \\
\text { mass index) }\end{array}$} & \multicolumn{2}{|c|}{$\begin{array}{l}\text { Sum of skin } \\
\text { folds }(\mathrm{mm})\end{array}$} & \multicolumn{2}{|c|}{$\begin{array}{l}\text { Systolic blood } \\
\text { pressure }\end{array}$} & \multicolumn{2}{|c|}{$\begin{array}{c}\text { Diastolic } \\
\text { blood pressure }\end{array}$} \\
\hline & & & Mean & $\mathrm{SD}$ & Mean & $\mathrm{SD}$ & Mean & $\mathrm{SD}$ & Mean & $\mathrm{SD}$ & Mean & $\mathrm{SD}$ & Mean & $\mathrm{SD}$ \\
\hline & & & & & & & $M a$ & & & & & & & \\
\hline \multirow{2}{*}{$20-24$} & W & 421 & 176.9 & 7.2 & 75.6 & 13.3 & 1.38 & 0.07 & 25.3 & 12.5 & 124.9 & 13.2 & $76.9^{*}$ & 10.4 \\
\hline & B & 80 & 175.5 & 7.2 & 74.4 & 14.9 & 1.38 & 0.07 & 23.5 & 14.4 & 125.8 & 16.1 & 80.2 & 10.5 \\
\hline \multirow[t]{2}{*}{$25-34$} & W & 664 & $176.9^{* *}$ & 7.1 & 79.4 & 13.9 & 1.40 & 0.06 & 28.2 & 12.5 & 124.9 & 13.8 & 80.6 & 9.9 \\
\hline & B & 113 & 174.7 & 7.1 & 78.1 & 19.3 & 1.40 & 0.09 & 25.9 & 17.2 & 127.2 & 13.5 & 82.4 & 10.9 \\
\hline \multirow[t]{2}{*}{$35-44$} & W & 554 & 175.7 & 6.7 & 80.1 & 12.9 & 1.41 & 0.06 & 28.5 & 11.3 & $126.5^{* *}$ & 14.2 & $84.0^{* * *}$ & 11.0 \\
\hline & B & 79 & 174.5 & 7.2 & 79.9 & 16.6 & 1.41 & 0.08 & 28.9 & 15.4 & 135.9 & 19.2 & 90.7 & 13.3 \\
\hline \multirow[t]{2}{*}{$45-54$} & W & 636 & 174.8 & 6.7 & 78.9 & 13.5 & 1.41 & 0.07 & $28.8^{*}$ & 11.8 & $133.1^{* *}$ & 19.2 & $86.4^{* *}$ & 12.3 \\
\hline & B & 116 & 174.4 & 7.0 & 77.5 & 15.0 & 1.40 & 0.08 & 26.0 & 13.5 & 139.2 & 25.2 & 90.9 & 15.2 \\
\hline \multirow[t]{2}{*}{$55-64$} & W & 431 & 173.3 & 6.7 & 77.9 & 13.9 & 1.41 & 0.07 & 28.0 & 11.7 & $137.5^{*}$ & 20.4 & $85.3 * *$ & 11.5 \\
\hline & B & 69 & 173.1 & 6.6 & 78.2 & 17.8 & 1.41 & 0.08 & 26.5 & 14.5 & 144.2 & 24.6 & 90.9 & 14.4 \\
\hline \multirow[t]{2}{*}{$65-74$} & W & 1098 & 171.0 & 6.7 & $74.1^{* *}$ & 12.4 & $1.40^{* *}$ & 0.07 & $27.2^{*}$ & 11.4 & $143.3^{* *}$ & 23.1 & $83.8^{* *}$ & 12.6 \\
\hline & B & 221 & 170.9 & 6.6 & 71.3 & 13.4 & $\begin{array}{l}1.38 \\
\text { Femal }\end{array}$ & 0.07 & 23.8 & 12.7 & 153.8 & 28.3 & 88.6 & 13.9 \\
\hline \multirow[t]{2}{*}{$20-24$} & W & 951 & 162.8 & 6.4 & $60.3 * *$ & 12.7 & $1.35^{* *}$ & 0.08 & $35.3^{*}$ & 15.5 & 115.3 & 12.8 & 72.0 & 10.1 \\
\hline & B & 255 & 162.2 & 6.3 & 63.5 & 15.0 & 1.37 & 0.09 & 37.8 & 18.3 & 114.8 & 14.4 & 73.3 & 11.4 \\
\hline \multirow[t]{2}{*}{$25-34$} & W & 1524 & 162.6 & 6.3 & $62.7^{* *}$ & 14.0 & $1.37^{* *}$ & 0.08 & $38.8^{*}$ & 16.8 & $116.7^{* *}$ & 13.9 & $74.9^{* *}$ & 10.4 \\
\hline & B & 315 & 162.7 & 5.7 & 69.3 & 17.8 & 1.41 & 0.10 & 45.3 & 20.7 & 121.0 & 17.7 & 79.0 & 12.5 \\
\hline \multirow[t]{2}{*}{$35-44$} & W & 1240 & 162.6 & 6.4 & $65.6^{*}$ & 14.5 & $1.39^{* *}$ & 0.08 & $42.1^{* *}$ & 16.8 & $121.8^{* *}$ & 17.0 & $78.6^{* *}$ & 10.9 \\
\hline & B & 283 & 162.9 & 6.4 & 74.5 & 17.8 & 1.44 & 0.10 & 51.3 & 20.2 & 129.2 & 20.2 & 85.6 & 13.0 \\
\hline \multirow[t]{2}{*}{$45-54$} & $\mathbf{W}$ & 742 & 161.7 & 6.1 & $66.9^{*}$ & 14.2 & $1.40^{* *}$ & 0.08 & $45.4^{* *}$ & 16.8 & $129.2^{* *}$ & 20.2 & $81.6^{* * *}$ & 11.8 \\
\hline & B & 13 & 162.5 & 5.9 & 74.7 & 16.6 & 1.44 & 0.09 & 53.5 & 21.3 & 141.9 & 27.9 & 90.1 & 14.1 \\
\hline \multirow[t]{2}{*}{$55-64$} & W & 439 & 159.6 & 6.1 & $65.7 * *$ & 13.2 & $1.40^{* *}$ & 0.08 & $43.5^{* * *}$ & 16.0 & $140.5^{* *}$ & 24.1 & $84.6^{* *}$ & 12.1 \\
\hline & B & 74 & 160.4 & 7.0 & 73.9 & 19.2 & 1.45 & 0.10 & 51.5 & 20.4 & 150.7 & 28.2 & 90.5 & 14.5 \\
\hline \multirow[t]{2}{*}{$65-74$} & W & 1039 & 158.3 & 6.1 & $64.6 * *$ & 13.0 & $1.40^{* *}$ & 0.08 & $41.2^{*}$ & 14.8 & $148.0 * *$ & 23.8 & $84.2 * *$ & 12.1 \\
\hline & B & 193 & 159.1 & 6.1 & 70.0 & 16.0 & 1.43 & 0.09 & 45.9 & 17.5 & 160.6 & 27.6 & 88.9 & 14.9 \\
\hline
\end{tabular}

among whites are systematically lower than among blacks, which indicates that the intake of potassium relative to sodium is less in blacks than in whites. In contrast, Table 2 indicates that the systolic and diastolic blood pressures after the age of 35 years are significantly higher in blacks than in whites. It must be noted that the differences in blood pressure are not associated with concomitant differences in daily calorie intake, sum of skinfolds, or body size.

Because of the differences in $\mathrm{Na} / \mathrm{K}$ ratio, the comparisons of blood pressure between blacks and whites were adjusted for the effect of this variable by analyses of covariance. Table 3 shows that the tendency toward increased blood pressure of blacks continues even when the effects of the differences in the $\mathrm{Na} / \mathrm{K}$ ratio are corrected.

\section{DISCUSSION}

The present findings are unexpected in that the 24-hr dietary recall indicates that blacks have a lower, not higher, intake of sodium than do whites. These findings differ from

TABle 3. COMPARISON OF BLOOD PRESSURE ADJUSTED FOR DIFFERENCES IN SODIUM/POTASSILM RATIO OF BLACKS AND WHITES DERIVED

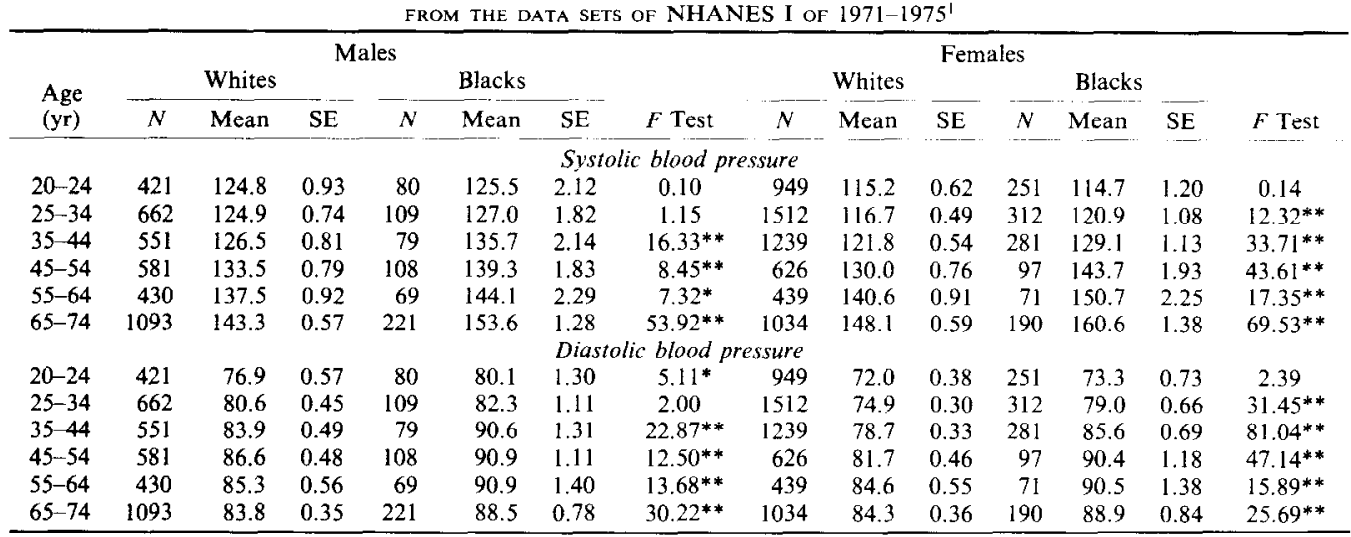

'Adjusted through analysis of covariance

${ }^{*} p<0.05, * * p<0.005$. 
previous reports [1-5]. In view of the fact that the present analyses are based upon a large and representative American sample [12-13] and assuming that any errors associated with the collection of the 24-hr dietary recall data were randomly distributed across all samples [13], it can be concluded that blacks do not have an increased dietary intake of sodium. They do have, however, a higher ratio of sodium to potassium intake, which agrees with previous studies [14-16]. It has been postulated that the higher blood pressure of blacks is related to this higher $\mathrm{Na} / \mathrm{K}$ ratio [14-19]. The finding that blacks adjusted for differences in $\mathrm{Na} / \mathrm{K}$ ratio did continue to maintain higher blood pressure than whites indicates that the increased prevalence of hypertension in blacks cannot be explained solely on the basis of differences in $\mathrm{Na} / \mathrm{K}$ ratio.

A major concern in all population studies is the reliability and representativeness of 24-hr dietary measurements. To validate any assessment of dietary sodium intake, one would need information on urinary sodium excretion. Unfortunately, urinary sodium excretion was not measured in NHANES I, and even had such a measurement been obtained it still would not be sufficient. This is because it has been estimated that eleven 24-hr periods of dietary assessment and collection would be necessary to typify individual sodium intake and produce correlations with urinary excretion data [20]. Obviously, such a type of measurement cannot be done in a large survey such as the present one.

Although the differences in blood pressure between whites and blacks in the present study cannot be attributed to differences in $\mathrm{Na} / \mathrm{K}$ ratio, it is conceivable that blacks are more sensitive to the effects of sodium on blood pressure than whites. Helmer [21] and later Gleibermann [22] postulated that since blacks evolved in the hot environment of the African continent conducive to copious sweating and salt loss and the lack of sodium available in natural foods, they may have evolved more efficient mechanisms of conserving sodium. This state would have been adaptive in non-industrialized populations but may be maladaptive in an environment where dietary sodium is high. This hypothesis is supported by experimental studies indicating that when given a normal i.v. saline solution, blacks excreted salt more slowly than whites [23]. Furthermore, when blacks and whites were given high dietary intakes of sodium, significant increases in blood pressure in the blacks occurred at a sodium intake of $800 \mathrm{mEq} /$ day and at $1200 \mathrm{mEq} /$ day for whites [24]. In other words, the threshold at which blood pressure increases with salt intake is lower in blacks than whites.

In agreement with previous reports [6-7], the present study indicates that blacks ingest less potassium than whites. It is quite possible that the low potassium intake along with an increased susceptibility to salt may be important in the development of hypertension in both blacks and whites. The genetic mechanism associated with this increased sensititivity in blacks remains to be defined. One productive way to do this would be to determine the interrelationship of genetic markers, nutritional factors and blood pressure. In view of the fact that skin color is genetically determined and its phenotypic expression shows great variability, evaluating the relationship of this variability to blood pressure and environmental factors will provide valuable information toward the clarification of the nature-nurture problem of high blood pressure.

\section{REFERENCES}

1. Creditor MC, Loschky UK: Incidence of suppressed renin activity and of normokalemic primary aldosteronism in hypertensive negro patients. Circulation 37: 1027-1031, 1968

2. Channick BJ, Adkins EV, Marks AD: Suppressed plasma renin activity in hypertension. Arch Int Med 123: $131-140,1969$

3. Desor JA, Green LA, Maller O: Preferences for sweet and salty in 9 to 15 -year-old and adult humans. Science 190: $686-687,1975$

4. Karp RJ, Williams C, Grant J-O: Increased utilization of salty food with age among preteenage black girls. J Natl Med Assoc 72: 197-200, 1980

5. Watson RL, Langford HG, Abernethy $\mathrm{J}$, et al: Urinary electrolytes, body weight, and blood pressure: Pooled cross-sectional results among four groups of adolescent females. Hypertension 2: I-93-I-98, 1980

6. Grim CE, Luft FC, Miller JZ, et al: Racial differences in blood pressure in Evans County, Georgia: Relationship to sodium and potassium intake and plasm renin activity. J Chron Dis 33: 87-94, 1980

7. Luft FC, Grimm CE, Fineberg N, et al: Effects of volume expansion and contraction in normotensive whites, blacks and subjects of different ages. Circulation 59: 643-650, 1979 
8. Cruickshank JK, Beevers DG: Epidemiology of hypertension: Blood pressure in blacks and whites. Clin Sci 62: 1-6, 1982

9. Voors AW, Dalferes ER Jr, Frank GC, et al: Relation between ingested potassium and sodium balance in young blacks and whites. Am J Clin Nutr 37: 583-594, 1983

10. Johnson $\mathrm{CL}$, Fulwood $\mathrm{K}$, Abraham S, et al: Basic data on anthropometric measurements and angular measurements of the hip and knee joints for selected age groups 1-74 years of age: United States, 1971-1975. DHHS Publication No. (PHS) 81-1669. Hyattsville, Md: National Center for Health Statistics, 1981

11. Roberts J, Maurer K: Blood pressure levels of persons 6-74 years: United States, 1971-1974. DHEW Publication No. (HRA) 78-1648. Hyattsville, Md: National Center for Health Statistics, 1977

12. Abraham S, Carroll MD, Dresser CM, et al: Dietary intake source data, United States, 1971-1974. DHEW Publication No. (PHS) 79-1221. Hyattsville, Md: National Center of Health Statistics, 1979

13. Harlan WR, Hull AL, Schmouder RP et al: Dietary intake and cardiovascular risk factors, part I. Blood pressure correlates: United States, 1971-75. DHHS Publication No. (PHS) 83-1676. Hyattsville, Md: National Center for Health Statistics, 1983

14. Tryoler HA et al: Weight and hypertension. In International Symposium on the Epidemiology of Hypertension. Vol. 2, Hypertension-prevention and control. Paul O. (Ed.) New York: Stratton Intercontinental Medical Book Corporation, 1975. pp. 177-201

15. Chiang BN, Perlam LV, Epstein FH: Overweight and hypertension: A review. Circulation 39: 403-421. 1969

16. Mann GV: The influence of obesity on health. N Engl J Med 291: 178-185, 226-232, 1974

17. Langford HG, Watson RL, Thomas JG: Salt intake, diuretics, and the treatment of hypertension. Trans Am Clin Climatol Assoc 88: 32-37, 1976

18. Grim CE, McDonough Jr, Dahl LK, et al: On the higher blood pressure of blacks: A study of sodium and potassium intake and excretion in a biracial community. Clin Res 18: 593, 1970

19. Meneely GR, Ball COT, Youmans JB: Chronic sodium chloride toxicity: The protective effect of added potassium chloride. Ann Int Med 47: 263-273, 1957

20. Liu K, Cooper R, Soltero I, Stamler J: Variability in 24-hr urine sodium excretion in children. Hypertension 1: 631-636, 1979

21. Helmer OM: Hormonal and biochemical factors controlling pressure. In Les Concepts de Claude Bernard Sur le Milieu Interieur. Paris: Masson, 1967. pp. 115-128

22. Gleibermann LK: Aspects of sodium metabolism: Implications for population variation in blood pressure. Ph. D. Dissertation. University of Michigan, 1975

23. Luft FC, Grim CE, Higgins JT, et al: Differences in response to sodium administration in normotensive black and white subjects J Lab Clin Med 90: 555-562, 1977

24. Luft FC, Bloch R, Weyman A, et al: Cardiovascular responses to extremes of salt intake in man. Clin Res 26: 365A, 1978 